STUDIA PRAWNO-EKONOMICZNE, T. CXIII, 2019

PL ISSN 0081-6841; e-ISSN 2450-8179 s. 31-51

https://doi.org/10.26485/SPE/2019/113/2

\title{
Beata GIESEN*
}

iD https://orcid.org/0000-0003-3962-9482

\section{PRAWO CYWILNE WOBEC POTRZEBY OCHRONY OSÓB Z DEMENCJA - ANALIZA Z PERSPEKTYWY PRAWA NIEMIECKIEGO}

\begin{abstract}
Abstrakt
Przedmiot badań: Zjawisko starzenia się społeczeństwa stawia prawników przed koniecznością rozwiązania szeregu nowych, nieznanych dotąd problemów, jak chociażby te związane z zastosowaniem nowych technik. Powszechne są też głosy o potrzebie stworzenia nowej filozofii uwzględniającej specyficzną sytuację osób cierpiących na chroniczne zaburzenia pamięci. Chorobom takim jak Alzheimer towarzyszą bowiem trwałe zaburzenia procesu podejmowania decyzji i wyrażania woli. Prowadzi to często do postawienia pytania o faktyczną zdolność do działań osób dotkniętych takim schorzeniem oraz o kwestię ich reprezentacji oraz opieki nad nimi.

Cel i sposób prowadzonych badań: Potrzeba kompleksowego uregulowania sytuacji prawnej osób cierpiących na demencję staje się coraz pilniejsza, również w prawie polskim. W tym względzie przydatne okazać się może skorzystanie z doświadczeń państw zachodnich, w tym w szczególności z rozwiązań niemieckich. Prezentacja doświadczeń naszych sąsiadów może być dobrym punktem wyjścia dla rozważań na gruncie prawa polskiego.

Wnioski: Nauka niemiecka znajduje się dopiero na początku drogi zmierzającej do wypracowania koncepcji ochrony takich osób. Pierwszy krok został już uczyniony, jest nim przeniesienie pojęć używanych do tej pory wyłącznie w sferze medycyny na płaszczyznę prawa cywilnego. W prawie niemieckim nie występuje obecnie możliwość całkowitego ubezwłasnowolnienia. Dopuszczalne jest jedynie ograniczenie, pod pewnymi warunkami, zdolności do czynności prawnych w ustalonym przez sąd opiekuńczy zakresie. Podopieczny zachowuje prawo do dokonywania czynności prawnych, sąd może jednak uzależnić skuteczność tej czynności od zgody opiekuna. Sam fakt ustanowienia opieki dla osoby chorej nie przesądza jeszcze o ograniczeniu tejże zdolności. W prawie niemieckim nie jest nigdy możliwe pozbawienie osoby chorej zdolności do dokonywania rozporządzeń na wypadek śmierci. Osoba dotknięta demencją zachowuje zwykle pełną zdolność do dokonywania czynności prawnych. Jak się wydaje, przyjęta w niemieckim systemie koncepcja naturalnej zdolności do czynności prawnych, zwana też zdolnością do działań, w pełni pozwala zabezpieczyć osobę cierpiącą na demencję przed negatywnymi konsekwencjami działań podejmowanych przez nią w stanie wyłączenia lub znacznego ograniczenia swobody w kształtowaniu swojej woli. Jeśli bowiem zaburzenia pamięci miały wpływ na ukształtowanie woli, dokonana
\end{abstract}

* Dr hab., prof. UŁ, Uniwersytet Łódzki, Wydział Prawa i Administracji, Katedra Prawa Cywilnego; e-mail: bgiesen@binar.pl 
czynność będzie uznana za nieważną. Mankamentem takiego rozwiązania jest niewątpliwie to, że ocena ważności czynności prawnej może być dokonana wyłącznie ex post. Takie podejście jest efektem przekonania, że chory na demencję zachowuje prawo do samostanowienia o sobie, w tym także do zawarcia małżeństwa. Ważną rolę w procesie ochrony interesów osób z dysfunkcją pamięci spełnia możliwość udzielenia przez nie same, wcześniej, gdy są one jeszcze zdrowe, pełnomocnictwa do sprawowania nad nimi opieki na wypadek choroby oraz wprowadzone niedawno do niem. k.c. przepisy o tzw. „testamencie pacjenta”, które umożliwiają każdej pełnoletniej osobie wyrażenie woli postępowania z nią na wypadek, gdyby wyrażenie takiej woli w przyszłości z powodu choroby nie było już możliwe albo znacznie utrudnione.

Słowa kluczowe: Alzheimer, opieka, zakłócenia pamięci, dyspozycje pacjenta, pełnomocnictwo do sprawowania opieki.

\section{Wprowadzenie}

Prawo do samostanowienia należy do podstawowych zasad powszechnie przyjmowanych w europejskich systemach prawnych ${ }^{1}$. Jego realizacja opiera się na swobodzie podejmowania decyzji i wyrażania woli przez człowieka. Niezbędnym do tego warunkiem jest niczym niezakłócona, poprawnie funkcjonująca pamięć ludzka. Jedynie wówczas możliwe jest zapoznanie się ze stanem faktycznym leżącym u podłoża podejmowanej decyzji. Rozważenie wszystkich „za” i „przeciw” wymaga bowiem zawsze czerpania z zapisanych w ludzkiej pamięci informacji oraz doświadczeń².

Zainteresowanie cywilistów konsekwencjami zakłócenia pamięci u osób fizycznych nie jest zjawiskiem nowym. Już prawnicy rzymscy zastanawiali się, jakie znaczenie mają zaburzenia czynności psychicznych dla ważności zawieranych umów. Furiosus nullum negotium gerere potest, quia non intelligit, quid agat - brzmi słynny cytat z Gaiusa do czynności ${ }^{3}$. Zasada ta przez wiele wieków kształtowała podejście prawników europejskich wobec zagadnienia zdolności prawnej oraz ubezwłasnowolnienia osób, które ze względu na zakłócenia czynności psychicznych nie są w stanie kierować własnym postępowaniem. Zainteresowanie tą problematyką w sposób wyraźny przybrało jednak na sile w ostatnich latach, także, a może przede wszystkim, w związku z coraz większą

1 R. Damm, Medizinrechtliche Grundprinzipien im Kontext von Pflege und Demenz - „Selbstbestimmung und Fürsorge", Medizinrecht 2010/28, s. 451-455.

2 Na temat znaczenia pamięci oraz jej zakłóceń w procesie podejmowania decyzji patrz: C. Cording, N. Nedopil, Psychiatrische Begutachtung im Zivilrecht, Wydawnictwo Pabst Science Publishers, Lengerich 2017, s. 49-56.

3 Podaję za A. Thier, Entmündigung, Betreuung und Handlungsfähigkeit: Rechtshistorische Perspektiven, w: M. Schmoeckel (red.), Demenz und Recht, Baden-Baden 2010, s. 75. 
liczbą osób cierpiących na różnego rodzaju zaburzenia pamięci. W Niemczech szacuje się, że już w chwili obecnej ok. 1,4 miliona osób cierpi na demencję ${ }^{4}$, z czego dwie trzecie to zaburzenia mające swe źródło w chorobie Alzheimera. Prognozuje się, że w ciągu najbliższych trzydziestu lat liczba ta podwoi się. Przyczyna tego zjawiska jest oczywista. Za sprawą wydłużającej się długości życia wzrasta również liczba osób cierpiących na zaburzenia pamięci. Według prognoz, w Niemczech, w roku 2030 aż 20 milionów mieszkańców osiągnie wiek powyżej 65 lat, a jak widomo, istnieje bezpośrednia zależność pomiędzy długością życia a częstotliwością występowania zaburzeń pamięci. Wedle źródeł, z chwilą ukończenia 65. roku życia prawdopodobieństwo demencji podwaja się co pięć lat, tak że w wieku 90 lat wynosi aż 35\% ${ }^{5}$. Według niektórych źródeł już obecnie co trzeci mieszkaniec Niemiec powyżej 85. roku życia cierpi na chorobowe zakłócenia pamięci ${ }^{6}$.

Demencja zwykle łączona jest $\mathrm{z}$ chorobą Alzheimera, ponieważ problemy z pamięcią są jej najpoważniejszym, choć nie jedynym przecież, syndromem. W jednej trzeciej przypadków zaburzenia pamięci mają jednak inne niż ww. choroba podłoże $\mathrm{e}^{7}$ Z punktu widzenia prawa cywilnego nie bez znaczenia jest fakt, że utrata pamięci nie następuje nagle, a jest następstwem zwykle rozciągniętego w czasie procesu. Początkowo naruszeniu podlega pamięć krótkotrwała, a dopiero z czasem, w wyniku nieodwracalnych zmian w mózgu, dochodzi do dysfunkcji pamięci długotrwałej. Konsekwencją osłabienia, a następnie najczęściej całkowitej dysfunkcji pamięci jest utrata zdolności dokonywania osądu otaczającej rzeczywistości. Schorzenie to niesie ze sobą jeszcze i inne poważne dolegliwości, które nie są obojętne dla rozważań nad pozycją prawną osób nim dotkniętych. Jak wiadomo, osoby cierpiące na chorobę Alzheimera wykazują nierzadko skłonności do urojeń, doznają zaburzeń zdolności koncentracji, stają się labilne emocjonalnie, co przejawia się w zmienności nastrojów. Chorzy ci wykazują też tendencje do bezwolnego uciekania z miejsca pobytu oraz błąkania się po okolicy bez celu. Statystki podają, że od zdiagnozowania choroby do

4 Jako syndrom demencji uznaje się w medycynie chroniczne, tzn. trwające dłużej niż 6 miesięcy ograniczenie zdolności pamięci, któremu towarzyszą dalsze zakłócenia, takie jak: ograniczenie zdolności oceny, możliwości myślenia, a w efekcie również ograniczenie aktywności codziennego życia. Dokładne dane statystyczne obrazujące strukturę zachorowań na demencję dostępne są na stronie http://demenz-brandenburg.de/wp-content/uploads/2017/02/Daten -Zahlen 2016-10-von-DALZG.pdf; stan na 8.10.2019 r.

5 M. Böckmann, Die Demenzerkrankung als Hauptursache für Vorsorgemaßnahmen, Familie Partnerschaft Recht 2004/12, s. 648-654.

6 C. Cording, N. Nedopil, op. cit., s. 69.

7 M. Böckmann, op. cit., s. 651-652. 
momentu śmierci pacjenta upływa zwykle od 8 do 10 lat. Opisane problemy zdrowotne nie pozostają obojętne, co oczywiste, dla sytuacji zarówno życiowej, jak i prawnej chorego. Ponieważ liczba osób dotkniętych tym schorzeniem stale rośnie, coraz częściej dostrzega się konieczność wypracowania kompleksowego modelu ochrony, a nawet nowej filozofii wyznaczającej paradygmaty dla reguł prawnych oraz etycznych dla postępowania $\mathrm{z}$ osobami dotkniętymi zaburzeniami pamięci ${ }^{8}$. Szacuje się, że w chwili obecnej $2 / 3$ takich osób pozostaje pod opieką członków rodziny. Dla prawidłowego funkcjonowania tej pomocy niezbędne jest wsparcie ze strony zarówno państwa, jak i gmin. Potrzeba ta dostrzegalna jest na wielu płaszczyznach życia społecznego i nie ogranicza się wyłącznie do kwestii zapewnienia odpowiedniej opieki medycznej. Niezwykle ważna jest również pomoc socjalna, której spektrum jest szerokie, począwszy od udzielania porad w sprawach organizacji życia, przekazywania informacji o możliwościach diagnostycznych oraz terapeutycznych, pomoc w pracach domowych, np. poprzez świadczenie serwisu żywieniowego, organizowanie aktywności ruchowej chorego, aż po wspieranie psychologiczne rodziny chorego. Ważnym elementem modelu ochrony jest również organizowanie tzw. wspólnot mieszkaniowych, przeznaczonych dla ludzi z demencją we wczesnym jej stadium9 9

Wzrastająca stale liczna osób z demencją jest bodźcem do podejmowania analiz naukowych $\mathrm{w}$ różnych obszarach prawa, w tym również $\mathrm{w}$ obrębie prawa cywilnego. Zaburzenia pamięci odgrywają bowiem istotną rolę w procesie oceny oświadczeń woli składanych przez osobę dotkniętą tego typu schorzeniem. Dokonując pewnego uproszczenia, można wskazać na następujące obszary, gdzie kwestia ta nabiera szczególnego znaczenia: po pierwsze, w zakresie oceny naturalnej zdolności do czynności prawnych, w szczególności zaś zdolności do testowania; po drugie, przy rozważaniach na temat pełnomocnictwa do sprawowania opieki na wypadek, gdyby mocodawca nie był stanie sam kierować swoimi sprawami życiowymi (Vorsorgevollmacht); po trzecie, w ramach omawiania instytucji opieki ustanawianej przez sąd w celu sprawowania zarządu i kontroli

8 M. Schmoeckel, Demenzerkrankungen als gesellschaftliche Herausforderung und Aufgabe für Juristen, w: M. Schmoeckel (red.), Demenz und Recht, s. 13-25.

9 Tytułem przykładu wskazać można na § 71 SGB XII - regulujący problematykę pomocy osobom starszym na poziomie komunalnym, szereg nowych form opieki nad takimi pacjentami przewiduje ustawa „Zur Neuausrichtung der Pflegeversicherung” (§ 38 a SGB XI PNG, § 45 lit. a-c SGB XI PNG). Ustawa ta przewiduje dodatkowe świadczenia pieniężne dla osób cierpiących na demencję oraz ułatwiony dostęp do świadczeń opiekuńczych, na ten temat obszernie M. Schölkopf, H. Hoffer, Das Erste Pflegestärkungsgesetz (PSG I) - Inhalte und Bedeutung für die pflegerische Versorgung, Neue Zeitschrift für Sozialrecht 2015/14, s. 521-531. 
nad interesami podopiecznego, i w końcu czwartą płaszczyznę wyznaczają rozważania o potrzebie ochrony dóbr osobistych wobec niebezpieczeństwa ich naruszenia przy okazji posługiwania się nowymi technologiami w procesie opieki nad chorym z demencją.

\section{Znaczenie stanu demencji dla oceny naturalnej zdolności do działań}

Zjawisko wzrastającej z roku na rok liczby pacjentów z objawami chronicznej demencji prowadzi do pytania o jego znaczenie dla oceny zdolności do czynności prawnych osób nią dotkniętych. Dla dokładnego objaśnienia konsekwencji, jakie mają zaburzenia pamięci dla faktycznej zdolności do czynności prawnych człowieka, określanej w nauce niemieckiej pojęciem zdolności do działań (Geschäftsfähigkeit), konieczne jest poczynienie kilku uwag natury ogólnej. Pod pojęciem zdolności do czynności prawnej nauka niemiecka rozumie mianowicie zdolność człowieka do tego, aby samodzielnie dokonywać w pełni skutecznych czynności prawnych ${ }^{10}$. Nieważne jest oświadczenie woli złożone przez osobę niezdolną do dokonywania czynności prawnych. Podobnie nieważne jest oświadczenie woli złożone w stanie braku świadomości albo przemijającego zaburzenia władz umysłowych.

Prawo niemieckie wyznacza jedynie dolną granicę wieku, którego osiągnięcie jest niezbędne dla uzyskania zdolności do czynności prawnej. Zgodnie z $\S 104$ niem. k.c. (BGB) całkowicie niezdolny do dokonywania czynności prawnych jest małoletni, który nie ukończył 7. roku życia. Nie wprowadza się natomiast górnej granicy wieku, którego osiągnięcie miałoby wpływ na zakres wspomnianej zdolności. W prawie niemieckim brak jest formalnych kryteriów, pozwalających z góry wyłączyć zdolność do czynności prawnych, niezależnie od faktycznego stanu umysłowej sprawności człowieka w momencie dokonywanej czynności ${ }^{11}$. W 1992 r. uchylono przepisy dopuszczające orzeczenie całkowitego ubezwłasnowolnienia. W konsekwencji osoba z zaburzeniami czynności psychicznych nie może być pozbawiona w drodze orzeczenia sądowego zdolności do czynności prawnej, możliwe jest jedynie punktowe, ograniczone do pewnej kategorii czynności, wyłączenie tej zdolności. Istotne jest to, że sam fakt ustanowienia opiekuna nie przesądza o ograniczeniu zdolności do czyn-

10 Patrz na ten temat H.-P. Mansel, w: R. Stürner (red.), Jauernig, Bürgerliches Gesetzbuch. Kommentar, Monachium 2015, s. 48.

11 Na temat pojęcia faktycznej zdolności do działań w literaturze polskiej patrz B. Lewaszkiewicz-Petrykowska, Wady oświadczenia woli, Warszawa 1973, s. 35. 
ności podopiecznego. Będzie na ten temat mowa w dalszej części rozważań. Ocena zdolności do czynności prawnych, z wyjątkiem sytuacji wskazanych powyżej, może być dokonywana zatem wyłącznie na tle konkretnego stanu faktycznego. Materialne kryterium oceny naturalnej zdolności do czynności prawnej wprowadza $\S 104$ pkt 2 niem. k.c. (BGB), który brzmi: „kto znajduje się w stanie chorobowego zaburzenia władz umysłowych, wyłączającym swobodne wyrażenie woli o ile stan ten z natury swej nie jest przemijającym” (§ 104 pkt 2. 105 niem. k.c. (BGB). Dodatkowe kryteria oceny niezdolności wynikają z powołanego wyżej punktu $2 \S 105$ niem. kodeksu cywilnego (BGB)), gdzie, przypomnijmy, wskazuje się na stan nieświadomości oraz stan przemijających zaburzeń czynności umysłowych jako na okoliczności, które mogą być źródłem braku zdolności do czynności prawnych ${ }^{12}$. Ocena tego, czy w konkretnej sytuacji osoba fizyczna posiadała faktyczną zdolność do działania, odbywa się na dwóch płaszczyznach. Najpierw należy ustalić, czy u badanej osoby w chwili dokonywania przez nią czynności prawnej występowały objawy chorobowe, które, obiektywnie rzeczy ujmując, mogły być źródłem zakłócenia procesu podejmowania decyzji i wyrażania woli, a następnie sprawdza się, czy skutek tej choroby, tj. zakłócenie procesu podejmowania decyzji i wyrażenia woli miał wpływ na ukształtowanie woli podmiotu dokonującego określonej czynności ${ }^{13}$.

Dla oceny faktycznej zdolności do czynności prawnych osób fizycznych dotkniętych demencją istotną rolę odgrywają towarzyszące tym zaburzeniom urojenia. W nauce przedmiotu podaje się, że syndrom paranoidalny może przemawiać za brakiem zdolności do czynności prawnych wówczas, gdy istnieje związek pomiędzy urojeniami a treścią dokonanej czynności prawnej. Warto odnotować, że zasada ta znajduje zastosowanie także w procesie oceny zdolności testowania ${ }^{14}$. Testament, podobnie jak to ma miejsce $w$ prawie polskim, jest w prawie niemieckim czynnością osobistą. Nie jest zatem dopuszczalne sporzą-

12 W literaturze przedmiotu podnosi się, że pomimo pojęciowej różnicy pomiędzy kryteriami właściwymi dla oceny zdolności do czynności prawnych, którymi posługuje się ustawodawca w tych dwóch przepisach, tj. w $\S 104$ oraz $\S 105$ niem. kodeksu cywilnego (BGB), praktyka nie przywiązuje nadmiernej wagi do różnicy pomiędzy tymi pojęciami, przypisując znaczenie różnicy pomiędzy nimi wyłącznie względom historycznym.

13 M. Schäfer, Der Demenzkranke im Familienrecht, Neue Zeitschrift für Familienrecht (NZFam), z. 15, Wydawnictwo C.H. Beck, s. 676.

$14 \S 2229$ ust. 4 niemieckiego kodeksu cywilnego (BGB) mówi: „Nie może sporządzić testamentu ten, kto z powodu, mających swe źródło w chorobie, zaburzeniach czynności umysłowych, ułomności umysłowych lub z powodu zaburzeń świadomości nie jest w stanie zrozumieć znaczenia złożonego przez siebie oświadczenia woli i odpowiednio do tego zrozumienia postępować". Na marginesie warto zaznaczyć, że zdolność do czynności prawnych nie jest 
dzenie go przez pełnomocnika, względnie przez opiekuna ustanowionego przez sąd. Poza tym, w przeciwieństwie do innych czynności, nie jest możliwe sądowe wyłączenie zdolności do testowania. Zgodnie z regułami prawa procesowego, obowiązek udowodnienia braku zdolności do czynności prawnej obciąża tę stronę, która na tę okoliczność się powołuje ${ }^{15}$.

Przywołane reguły znajdują swoje odbicie w sprawach związanych z ustalaniem zdolności do czynności prawnej osób cierpiących na demencję. Należy odnotować, że w prawie niemieckim nie jest możliwa ocena zdolności do czynności prawnej określonej osoby ex ante. Toteż nawet wobec osób z zaawansowaną demencją założenie o zdolności do czynności prawnej zachowuje swą aktualność. Wychodzi się bowiem z założenia, że posiadają one pełną zdolność do czynności prawnych. Ocena tego, czy podmiot dokonujący czynności posiadał w danej chwili tę właściwość może być dokonywana wyłącznie ex post. Przyjęte rozwiązanie stanowi gwarancję ochrony osób chorych. Znajduje ono oparcie w ustaleniach naukowych współczesnej psychologii. Zgodnie z nimi nie można z góry założyć, że człowiek jest albo nie jest autonomiczny i świadomy konsekwencji swoich zachowań. Nawet bowiem osoby z zaawansowaną chorobą Alzheimera w pewnych sferach zachowują pełną świadomośćc ${ }^{16}$. Dlatego ocenie poddane może, i powinno, podlegać wyłącznie określone zachowanie człowieka. W konsekwencji uznaje się, że nawet osoby z zaawansowaną demencją są zdolne, co do zasady, do dokonywania czynności prawnych. Trzeba jednak odnotować, że rozwiązanie to, choć oparte niewątpliwie na szczytnych założeniach, nie zawsze prowadzi do pożądanych rezultatów, nie zawsze też jest ono gwarantem ochrony osób cierpiących na chorobę otępienną. Problem $\mathrm{z}$ realizacją kodeksowej zasady zauważalny jest w praktyce przede wszystkim w przypadku badania zdolności do testowania. W przeciwieństwie do innych kategorii czynności ani jej ograniczenie, ani tym bardziej całkowite jej pozbawienie nie jest możliwe $\mathrm{w}$ drodze orzeczenia sądowego. W prawie niemieckim zakłada się, że każdy człowiek ma zdolność do testowania z chwilą ukończenia

jednak wymagana dla przyjęcia spadku. Szerzej na ten temat W. Grunsky, Testierfähigkeit und Geschäftsfähigkeit, Baden-Baden 2009.

15 Jest to ogólna zasada przyjęta w prawie niemieckim, która nie ma jednak wyraźnej podstawy prawnej. Bliżej na ten temat J. Ellenberger, w: Palandt. Bürgerliches Gesetzbuch, Monachium 2017, s. 83, a także C. Cording, N. Nedopil, op. cit., s. 35.

16 M. Schäfer (Der Demenzkranke..., s. 676-677) podaje przykład znajomego muzyka cierpiącego na chorobę Alzheimera, który nie był wprawdzie w stanie ułożyć w odpowiedniej kolejności nut przed koncertem, potrafił jednak z najwyższą precyzją odtworzyć w całości utwór, którego wykonania nauczył się w przeszłości. 
16. roku życia (§ 2229 niem. ust. 1 k.c. (BGB)). Zasada ta obowiązuje również wobec osób, dla których z uwagi na ich stan zdrowia ustanowiono opiekuna. Inaczej mówiąc, ani sam fakt stwierdzenia demencji, ani nawet ustanowienie dla osoby na nią cierpiącej opiekuna nie przesądzają jeszcze o braku zdolności do testowania (§ 1896 niem. k.c. (BGB) $)^{17}$. Podobnie stwierdzenie częściowego braku zdolności do czynności prawnej nie przesądza o braku zdolności do testowania. Rozstrzygający jest zawsze stan z chwili dokonania czynności, a dokładnie z chwili, w której złożony został podpis pod treścią rozporządzenia $^{18}$. Stwierdzenie braku zdolności do testowania przed i po dacie sporządzenia testamentu może uzasadniać jedynie przypuszczenie, że również w chwili sporządzenia testamentu testator tej zdolności był pozbawiony. Wedle judykatury niemieckiej nawet wysoki stopień demencji nie zwalnia z ustalenia, że w momencie sporządzenia testamentu testator był pozbawiony zdolności testowania $^{19}$. Dla potwierdzenia istnienia tej zdolności wystarczy lucidum intervallum, tzn. krótki przebłysk świadomości w chwili dokonywania czynności prawneje ${ }^{20}$. Orzecznictwo kieruje się w tym względzie następującą zasadą: sąd powinien zakładać istnienie zdolności do testowania tak długo, jak długo „nie jest całkowicie przekonany" o jej braku ${ }^{21}$. Dla potwierdzenia zdolności testowania nie wystarcza, że spadkodawca zdawał sobie sprawę z faktu sporządzenia testamentu oraz z jego treści. Wymaga się nadto, aby był on zdolny do wyrażania sądu o zakresie dokonywanego rozporządzenia oraz o jego skutkach. Testator powinien zatem działać swobodnie, świadom motywów swojego zachowania. W literaturze przedmiotu podkreśla się, że stan ten tylko wówczas może zostać potwierdzony, gdy spadkodawca był zdolny do przywołania w swojej pamięci zdarzeń z przeszłości, do przyswajania sobie informacji z otaczającej go rzeczywistości oraz do ich analizy ${ }^{22}$.

17 Patrz na ten temat R. Stürner, w: R. Stürner (red.), Jauernig, Bürgerliches Gesetzbuch. Kommentar, Monachium 2015, s. 2201, a także Ch. Waldhoff, Die Testierfähigkeit Demenzkranker im Lichte des Verfassungsrechts, w: M. Schmoeckel (red.), Demenz und Recht, s. 59. Patrz na ten temat także Ch. Waldhoff, Die Testierfähigkeit Demenzkranker im Lichte des Verfassungsrechts, w: M. Schmoeckel (red.), Demenz und Recht, Wydawnictwo Nomos, 2010, s. 59 oraz powołane tam orzecznictwo, s. 61-63.

20 T. Wetterling, Psychopathologische Auffälligkeiten bei Demenz und deren Auswirkungen auf die Willensbildung - aus Sicht eines Neuropsychiaters, w: M. Schmoeckel (red.), Demenz und Recht, s. 39-41, a także M. Schäfer, op. cit., s. 679.

21 Tak np. wyrok bawarskiego Sądu Apelacyjnego (Bayerisches Oberstes Landesgericht) z dnia 31.1.1991 - Breg. 1 a Z 37/90, opub. NJW 1992/4, s. 248-250.

22 Bliżej na ten temat D. Weidlich, w: Palandt. Bürgerliches Gesetzbuch, s. 2487. 
Jak uczy analiza praktyki, nie zawsze jednak opisane rozwiązanie służy ochronie osób dotkniętych chorobą otępienną. W piśmiennictwie zwraca się uwagę na ograniczone możliwości dowodowe, w szczególności w przypadku osób starszych ${ }^{23}$. Oczywiście, w przypadkach demencji zaawansowanej w takim stopniu, że jest ona niemalże widoczna dla każdego, orzeczenie o braku zdolności do testowania ex post zwykle nie nastręcza większych trudności. Dostrzega się również negatywne strony przejętego rozwiązania. Od czasu do czasu zarówno w prasie codziennej, jak i w literaturze fachowej zgłaszane są wątpliwości w tym zakresie ${ }^{24}$. Zdarzają się bowiem przypadki izolowania od otoczenia najczęściej starszych, majętnych mężczyzn, zwykle przez świeżo poślubioną kobietę, do tego stopnia, że czyni to niemożliwym ex post dokonanie oceny omawianej zdolności do testowania ${ }^{25}$.

$\mathrm{Na}$ podobne problemy napotyka nauka niemiecka w przypadku oceny zdolności do zawarcia małżeństwa czy też do podejmowania czynności mających na celu jego rozwiązanie. Wprawdzie przepis $\S 1304$ niem. k.c. (BGB) zakłada, że nie może zawrzeć małżeństwa ten, kto nie posiada zdolności do działania, jednak, w oparciu o konstytucję, dopuszcza się zawarcie małżeństwa przy tzw. ograniczonej zdolności. Spełnienie tej przesłanki potwierdza urzędnik poprzez przeprowadzenie odpowiedniego wywiadu z nupturientami. Nie wchodząc w szczegóły, nie ma przeszkód, które z góry wykluczyłyby możliwość wstąpienia w związek małżeński przez osobę ciepiąca na zaburzenia pamięci, konieczne jest jedynie, aby w chwili zawierania małżeństwa rozumiała ona jego istotę. Komentatorzy podają, że w takich sytuacjach wystarcza, jeśli małżonek pragnący zawrzeć małżeństwo dysponuje podstawową wiedzą o małżeństwie i decyduje się na jego zawarcie w sposób nieprzymuszony. W razie wątpliwości co do posiadania zdolności do zawarcia małżeństwa urzędnik stanu cywilnego ma prawo zwrócić się do sądu z wnioskiem o zbadanie tej okoliczności. Z lektury orzecznictwa wynika, że szczególną grupę przypadków, w których to następuje, stanowią plany małżeńskie starszych, cierpiących na chorobę otę-

Tak wyraźnie C. Cording, N. Nedopil, op. cit., s. 70-73.

Ibidem, s. 75.

25 Podejrzenia takie wyrażane były np. przy okazji badania ważności testamentu zmarłego w roku 2010 właściciela browaru Bruno H. Schuberta, który na kilkanaście lat przed śmiercią poślubił o 63 lata młodszą kobietę, która następnie izolowała go przez kolejne miesiące od otoczenia do tego stopnia, że zbadanie zdolności testowania w chwili sporządzenia testamentu nie było możliwe. Podejrzenia te pogłębia fakt, że parę miesięcy po śmierci spadkodawcy w niewyjaśnionych okolicznościach stracił życie również jego osobisty lekarz, krótko po tym, jak został wezwany w celu złożenia wyjaśnień o stanie zdrowia swojego pacjenta; bliżej na ten temat https://de.wikipedia.org/wiki/Bruno_H._Schubert; stan na 8.10.2019 r. 
pienną mężczyzn, których wybranką jest zwykle, jak to określa się w literaturze, „znacząco" młodsza kobieta, nierzadko jego opiekunka. Jak podają biegli psychiatrzy, tego typu przypadki są szczególne ze względu na to, że nie jest pewne, czy decyzja o zawarciu związku małżeńskiego nie jest wynikiem psychicznego uzależnienia mężczyzny od swojej partnerki. W literaturze wskazuje się na trzy kryteria, do których powinien odwołać się biegły sporządzający opinię w tego typu sprawie. Wyrażają się one w następujących pytaniach: 1) czy badany zdaje sobie sprawę z konsekwencji zawieranego małżeństwa, w tym również z tych wynikających ze wzajemnych obowiązków małżeńskich, 2) czy potrafi w sposób adekwatny ocenić konsekwencje w sferze prawa spadkowego, 3) czy, biorąc pod uwagę sytuację, w której znajduje się badany, jest on w stanie rozważyć argumenty przemawiające „za” i „przeciw” zawarciu małżeństwa i czy dostrzega on alternatywę wobec planowanego małżeństwa ${ }^{26}$.

Doskonałą ilustracją trudności pojawiających się na tym polu jest sprawa, która była przedmiotem rozstrzygnięcia Sądu Apelacyjnego z Hamm z dnia 16.08.2013 ${ }^{27}$. Stan faktyczny leżący u jej podłoża przedstawiał się następująco. Cieszący się w Niemczech dużą popularnością manager sportu - Rudi Assauer zawarł w 2011 r. związek małżeński z młodszą od siebie o 22 lata kobietą. Parę miesięcy później, cierpiący od 5 lat na demencję, małżonek udzielił swojej żonie pełnomocnictwa do sprawowania nad nim opieki, które już po 8 miesiącach odwołał. Wyprowadził się on też ze swojej willi, którą zajmował wraz z żoną, a następnie jego córka, która została ustanowiona przez sąd opiekunem, wniosła w jego imieniu powództwo o rozwód. Na marginesie dodajmy, że w prawie niemieckim czynność taka wymaga zawsze zgody sądu opiekuńczego. Żona, która była przeciwna rozwodowi, dowodziła przed sądem, że z całą pewnością mąż darzy ją, podobnie jak ona jego, w dalszym ciągu uczuciem, jego wyprowadzka zaś jest wyłącznie symptomem choroby, a ona sama jest gotowa sprawować dalej nad nim opiekę. Nie wchodząc w szczegóły, z uzasadnienia orzeczenia wynika jednak, że jej głównym motywem było uzyskanie profitów majątkowych po śmieci męża. Na tle takiego stanu faktycznego z łatwością można dostrzec wagę pytania o to, czy osoba dotknięta demencją zdaje sobie sprawę z istoty małżeństwa. Kwestia badania woli cierpiącego na demencję współmałżonka odgrywa rolę na wielu etapach postępowania o rozwód. Wątpliwości w tym względzie mogą pojawić się już na samym początku. Niemiecki kodeks cywilny wymaga

\footnotetext{
Na takie kryteria wskazuje C. Cording, N. Nedopil, op. cit., s. 78-79.

27 Wyrok Sądu Apelacyjnego z Hamm (Oberlandesgericht Hamm) z dnia 16.8.2013, NJW 2014/3, s. $158-162$.
} 
bowiem rocznej separacji małżonków. W przypadku osób z demencją zawsze powstaje pytanie, czy rozłąka była wynikiem świadomie podjętej woli, czy może raczej jednym z objawów chorobowych; podobnie badanie tzw. prognozy na przyszłość. Zgodnie z $§ 1565$ niem. k.c. (BGB) sąd powinien na rozprawie rozwodowej ustalić, czy małżonkowie widzą szanse na kontynuowanie wspólnego pożycia małżeńskiego. Wobec sytuacji, w której jeden z nich cierpi na demencję, judykatura wypracowała następującą regułę: jeśli proces demencji jest już tak dalece posunięty, że chory małżonek nie może wyrazić w sposób swobodny swojej woli, a to on złożył wniosek o rozwód, rozstrzygające znaczenie przypisuje się woli drugiego małżonka. Sędzia ma obowiązek zapytać go, czy chce on kontynuacji małżeństwa oraz czy ma świadomość odpowiedzialności z tym związanej. Jeśli zaś to zdrowy małżonek złożył wniosek o rozwód, pytanie o rozkład pożycia małżeńskiego zadawane jest tylko jemu. W omawianej sprawie sąd ostatecznie doszedł do wniosku, że przynajmniej w momencie składania wniosku powód posiadał wolę rozwodu. Argumentowano też, że z formalnego punktu widzenia wniosek został złożony poprawnie. Wyrok, pomimo zaskarżenia go przez pozwaną, został utrzymany w mocy.

\section{Pełnomocnictwo jako instrument ochrony interesów osoby cierpiącej na demencję}

Bardzo ważną rolę w ochronie interesów osób cierpiących na demencję odgrywa pełnomocnictwo do sprawowania opieki (Vorsorgevollmacht). Udzielenie tego typu upoważnienia jest w Niemczech na porządku dziennym. Dzieje się tak nie tylko z powodu pragmatycznego podejścia do spraw życiowych, ale także $\mathrm{z}$ uwagi na rozwiązania przyjęte $\mathrm{w}$ ramach kodeksowego uregulowania opieki. Zgodnie bowiem z § 1896 ust. 2 niem. k.c. (BGB) opiekunowi ustanowionemu przez sąd może być wyznaczony tylko taki zakres kompetencji, który jest niezbędny dla sprawowania opieki. Przesłanka ta nie jest zaś spełniona wówczas, gdy wcześniej zostało udzielone pełnomocnictwo o zakresie koniecznym dla sprawowania opieki nad mocodawcą. Inaczej rzecz ujmując, wiele osób prewencyjnie udziela pełnomocnictwa do sprawowania opieki na wypadek, gdyby w przyszłości zaszła konieczność jej sprawowania. W ten sposób pełnomocnictwo staje się instrumentem umożliwiającym zabezpieczenie własnych interesów, zarówno majątkowych, jak i osobistych, na wypadek utraty możliwości samodzielnego prowadzenia własnych spraw. Tego typu pełnomocnictwo znajduje ustawowe oparcie w $§ 164$ niem. k.c. (BGB), który zawiera ogólną 
regulację umocowania innej osoby do składania oświadczeń woli. W praktyce zakres udzielanego pełnomocnictwa jest szeroki. Obejmuje on w pierwszym rzędzie umocowanie do dokonywania czynności związanych z zarządem majątkiem, których dokonanie może okazać się konieczne w stanie choroby mocodawcy, ale nie tylko. Zwykle zawiera ono również szczegółowe zalecenia dla pełnomocnika, odnoszące się do spraw osobistych reprezentowanego, w tym również wskazówki dotyczące ewentualnej zgody na leczenie, bądź przeciwnie prawie odmowy takiej zgody na określone metody leczenia czy na stosowanie zabiegów leczniczych podtrzymujących życie, wskazania środków farmakologicznych, których mocodawca chciałby uniknąć albo na które z pewnością nie chce udzielić zgody. Zdarza się też, że pełnomocnictwo obejmuje upoważnienie do wyrażenia zgody na umieszczenie mocodawcy w odpowiednim ośrodku, jeśli okaże się to niezbędne $z$ uwagi na stan zdrowia mocodawcy, jak również na zastosowanie urządzeń umożliwiających jego lokalizację. Zakres swobody postępowania pełnomocnika $\mathrm{w}$ tym względzie jest jednak ograniczony przez $\S 1906$ niem. k.c. (BGB), który wyraźnie określa przesłanki umieszczenia podopiecznego w zakładzie w warunkach ograniczenia jego wolności. Niezależnie od zgody pełnomocnika, względnie opiekuna ustanowionego przez sąd, na umieszczenie w takim ośrodku zawsze wymagana jest zgoda sądu opiekuńczego (§ 1906 (2) niem. k.c. (BGB)).

Niemiecki kodeks cywilny przewiduje również inne, poza pełnomocnictwem, instrumenty umożliwiające osobie fizycznej wyrażenie, w sposób wiążący dla osób trzecich, woli o postępowaniu z nią na wypadek choroby (Patientenverfügung). Zgodnie z wprowadzonym w 2009 r. § 1901 lit. a niem. k.c. (BGB) każda pełnoletnia osoba fizyczna może na piśmie wyrazić swoją wolę co do sposobu postępowania $\mathrm{z}$ nią na wypadek choroby. W ten sposób działa ona niejako z wyprzedzeniem. Oświadczenie takie może być złożone, jeśli tylko jego podmiot nie znajduje się jeszcze bezpośrednio w sytuacji wymagającej podjęcia badania lekarskiego, procedury leczenia lub medycznej ingerencji. Rozporządzenie takie zwane jest często w literaturze „testamentem pacjenta"28.

28 Obszernie na ten temat Ch. Beermann, Die Patientenverfügung, FPR Familie Partnerschaft Recht 2010/6, s. 252-255, a także R. Coeppicus, Offene Fragen zum „Patientenverfügungsgesetz", NJW 2011/29, s. 2085-2091. 


\section{Opieka - jako środek sądowej ochrony interesów osoby cierpiącej na demencję}

Wobec osób cierpiących na demencję stosunkowo często ustanawiana jest opieka. Zgodnie z § 1896 ust. 1, zdanie 1 niem. k.c. (BGB) dla osoby pełnoletniej może być ustanowiony opiekun, jeśli z powodu choroby psychicznej albo cielesnego, umysłowego lub duchowego ograniczenia nie może ona w całości lub w części troszczyć się o własne sprawy. Zakres dopuszczalnej opieki w takich przypadkach nie jest uregulowany ustawowo. Jest on pozostawiony do kompetencji sądu. Sąd ma zatem swobodę zarówno co do zakresu, jak i sposobu w określeniu kompetencji opiekuna. Przepisy ustawy wyznaczają jedynie ogólne ramy opieki. $Z$ tego punktu widzenia znaczenie ma przede wszystkim $\S 1896$ ust. 2 zdanie 1 niem. k.c. (BGB). Powołany przepis określa nie tylko to, kiedy opieka może i powinna być ustanowiona, ale również jej możliwy do ustanowienia zakres. Może on mianowicie obejmować jedynie te zadania, względnie kategorie zadań, których osoba podopiecznego, rzeczywiście nie może wykonywać samodzielnie, tj. bez pomocy ustawowego opiekuna ${ }^{29}$. Trzeba zauważyć, że w konsekwencji tak sformułowanych ram dla instytucji opieki, w praktyce niemieckich sądów nie występuje prawie nigdy tzw. ,pełna opieka” (Vollbetreuung), która mogłaby być porównana ze znaną prawu polskiemu opiece ustanawianej dla osoby ubezwłasnowolnionej całkowicie.

Zgodnie z § 2229 niem. k.c. (BGB) domniemanie zdolności testowania obejmuje także osobę, dla której ustanowiono opiekę ${ }^{30}$. Osoba, dla której ustanowiono opiekuna jest zawsze uprawniona do wystąpienia $\mathrm{z}$ wnioskiem o uchylenie opieki. W tym względzie podopieczny dysponuje zawsze zdolnością procesową ${ }^{31}$. Z kolei $\S 1908$ lit. d. ust. 2, zdanie 2 niem. k.c. (BGB) stanowi, że, jeżeli opieka została ustanowiona na wniosek osoby wymagającej opieki, uchylenie opieki może nastąpić zarówno z urzędu, jak i na wniosek tejże osoby. Odpowiednio do wyżej powołanego przepisu wniosek ten może złożyć również osoba nieposiadająca zdolności do czynności prawnych. Powołane reguły znajdują również zastosowanie w sytuacji, w której chodzi jedynie o zmianę zakresu ustanowionej opieki ( 1908 d, ust. 1, zdanie 2, ust. 2, zda-

29 Por. co do szczegółów orzeczenie Niemieckiego Trybunału Związkowego (BGH) z dnia 6.7.2011, syg. XII ZB 80/11, op. Familienrechtszeitschrift FamRZ 2011/9, s. 1390-1391.

30 Por. D. Weidlich, w: Palandt, Bürgerliches Gesetzbuch, § 2229, numer boczny 5, 11, s. 2487, 2488.

31 Por. I. Götz, Palandt, Bürgerliches Gesetzbuch, § 1908d, numer boczny 26, s. 2256. 
nie 2 niem. k.c. (BGB). Prawo niemieckie odróżnia uchylenie opieki (Aufhebung der Betreuung) od zwolnienia dotychczasowego opiekuna (Entlassung des Betreuers) w celu ustanowienia nowego. Opieka może zostać uchylona w całości albo w części. W przypadku częściowego uchylenia opieki określa się zakres czynności, których osoba, dla której ustanawiana jest opieka, nie jest w dalszym ciągu w stanie wykonywać samodzielnie. Opieka ulega uchyleniu, gdy odpadły przesłanki jej ustanowienia. Jeśli zachodzą okoliczności uzasadniające uchylenie opieki, sąd podejmuje czynności z urzędu. Nie jest zatem konieczne złożenie wniosku przez jakąkolwiek osobę ${ }^{32}$.

\section{Ochrona godności osoby cierpiącej na demencję w orzecznictwie sądów niemieckich}

Zjawisko powiększającej się liczby pacjentów cierpiących na demencję skłania naukowców do pochylenia się nie tylko nad problematyką faktycznej zdolności do czynności prawnych takich osób. Coraz częściej stawiane są pytania o granice ochrony pacjenta w procesie leczenia przed nim samym oraz o dopuszczalne w tym zakresie środki. $W$ tym względzie podstawowe znaczenie odgrywa specyfika tej choroby. Jak wiadomo, nierzadko osoby cierpiące na zaburzenia pamięci, w szczególności zaś te, mające swe źródło w chorobie Alzheimera, nie są w stanie kierować swoim postępowaniem do tego stopnia, że same, własnym zachowaniem, narażają siebie na poważne niebezpieczeństwo utraty życia lub naruszenia zdrowia. Chodzi przede wszystkim o problem niekontrolowanych ucieczek osoby chorej z miejsca pobytu. Powszechnie znane są wypadki osób cierpiących na chorobę Alzheimera, które wychodzą z domu i nie są w stanie następnie do niego wrócić. Przy zaawansowanej dysfunkcji pamięci nie umieją one też odtworzyć swojego nazwiska ani wskazać danych dozwalających na skontaktowanie się z ich osobami bliskimi. Jak wiadomo, współcześnie dysponuje się takimi środkami technicznymi, które umożliwiają zlokalizowanie aktualnego miejsca pobytu człowieka. Do tego celu wykorzystywana jest technologia znana w literaturze pod nazwą technologii RFID ${ }^{33}$. Nie wchodząc w szczegóły, polega ona na umieszczaniu w garderobie chorego, najczęściej w butach, małej płytki, zawierającej w sobie chip - urządzenie, które umożliwia śledzenie cho-

32 Tak wyraźnie I. Götz, w: Palandt Bürgerliches Gesetzbuch, § 1908 lit. d, s. 2256, numer boczny 2 .

33 Obszernie na ten temat H. Kreicker, RFID-Technik in der Dementenversorgung - Herausforderungen für das Betreuungsrecht, NJW 2009/13, s. 890-894. 
rego. Chip ten jest przy tym zwykle jednym z elementów rozbudowanego systemu. Współgra on z płytkami indukcyjnymi umieszczanymi najczęściej w podłodze, przy wyjściu z budynku. Kiedy chory znajdzie się w jej zasięgu, dochodzi do nawiązania kontaktu pomiędzy chipem a płytką. Ta ostatnia z kolei wysyła sygnał do innego jeszcze urządzenia - czytnika EDV, które z kolei uruchamia albo sygnał dźwiękowy, albo optyczny, w każdym razie dochodzi w ten sposób do zaalarmowania osób sprawujących opiekę na chorym. Opisana technologia jest w praktyce wykorzystana w różnoraki sposób. Tytułem przykładu, przy jej pomocy można przez cały czas śledzić, w jakim pomieszczeniu w danej chwili przebywa, czy też skutecznie zablokować drzwi wyjściowe, umożliwiając w ten sposób samodzielne wydostanie się na zewnętrz. Jak łatwo się domyśleć, tego typu metody niosą ze sobą pytanie, czy ich zastosowanie nie narusza godności pacjenta. Posłużenie się nimi może być bowiem postrzegane jako ograniczenie wolności, wszak ograniczają one swobodę poruszania pacjenta. Poza tym, naruszona może zostać również jego sfera intymności i nienaruszalności cielesnej. Niektórzy autorzy krytycznie odnoszą się do pomysłu wykorzystywania opisanej technologii dla ochrony osób cierpiących na demencję $e^{34}$. Podnosi się bowiem, że wyposażenie chorego w chip może prowadzić do jego stygmatyzacji. Sceptycznie nastawieni wobec tej technologii naukowcy podnoszą też, że posłużenie się nią służy przede wszystkim odciążeniu personelu domów opieki. Dlatego ostatecznie w dyskusji nad dopuszczalnością posługiwania się opisaną technologią często pojawiają się głosy o zagrożeniu dla godności pacjenta, o jego poniżeniu czy też o sprowadzeniu go do roli obiektu. Na przeciwległym biegunie znajdują się natomiast liczni autorzy, którzy prezentują pogląd, że osąd na temat naruszenia godności ludzkiej nie powinien być nigdy formułowany in abstracto, bez należytego uwzględnienia wszystkich aspektów sytuacji, w której znajduje się osoba cierpiąca na demencję, oraz jego rodzina podnosząca zwykle ciężar opieki nad nią. Tak na przykład R. Damm podnosi ${ }^{35}$, że w przy ocenie tego typu zabezpieczeń technicznych nie należy zapominać o alternatywie dla niej, a w wielu wypadkach jest nią umieszczenie chorego w zamkniętym oddziale szpitalnym, co wiąże się przecież nie tylko z ograniczeniem możliwości wychodzenia na zewnątrz, ale również ze skrępowaniem swobody ruchów za pomocą odpowiednich pasów. Nie należy bagatelizować również niebezpieczeństwa obrażeń, na które naraża się chory podczas niekontrolowanych przez niego ucieczek z miejsca pobytu. Ostatecznie powołany wyżej autor uważa,

Tak np. ibidem, s. 892-893.

35 R. Damm, op. cit., s. 451. 
że w dyskusji nad dopuszczalnością posłużenia się tą technologią wiele zależy też od okoliczności konkretnej sprawy, z całą pewnością jednak sam fakt posłużenia się chipem nie uzasadnia jeszcze tezy o naruszeniu godności pacjenta względnie innych, chronionych prawem, sfer jego osobowości.

Omawiana problematyka jest również przedmiotem sporu na innej płaszczyźnie, chodzi mianowicie o pytanie, czy wyposażenie osoby cierpiącej na demencję w chipa wymaga zgody sądu opiekuńczego. Zgodnie z praktyką przyjętą w Niemczech w takich wypadkach zawsze wymagana jest zgoda pełnomocnika, względnie opiekuna. Nie jest natomiast jasne, w jakich sytuacjach konieczne jest dodatkowo uzyskanie zgody sądu opiekuńczego. Ogólnie rzecz ujmując, zgoda taka jest wymagana wtedy, gdy dochodzi do ograniczenia wolności pacjenta przy użyciu omawianej technologii, odpowiednio do zasady wyrażonej w § 1906 niem. k.c. (BGB). Rzecz w tym jednak, że nie jest do końca jasne, kiedy zastosowanie chipu prowadzi do ograniczenia wolności chorego. Powołany przepis rozróżnia bowiem pomiędzy dwoma postaciami ograniczenia wolności, a mianowicie pozbawieniem wolności związanym $\mathrm{z}$ ulokowaniem $\mathrm{w}$ zamkniętym pomieszczeniu oraz pozbawieniem wolności poprzez użycie innych sposobów, np. za pomocą środków mechanicznych czy podanie choremu odpowiednich lekarstw. W obydwu przypadkach wymagane jest uzyskanie zezwolenia sądu, które może być udzielone każdorazowo na okres nieprzekraczający dwóch lat. O ile jednak przy pierwszym typie ograniczenia wspominana zgoda poprzedzona musi być opinią biegłego psychiatry, w drugim przypadku wystarcza zwykłe zaświadczenie lekarskie, potwierdzające konieczność ograniczenia wolności w wybrany sposób. Ostatecznie sądy niemieckie przyjmują, że założenie chipa traktowane powinno być jako druga postać ograniczenia wolności ${ }^{36}$.

W judykaturze niemieckiej nie brak jednak odmiennych zapatrywań na dopuszczalność wyposażania osób z demencją w urządzenia kontrolujące ich przemieszczanie się. Dobrym przykładem jest stanowisko zajęte przed laty, a dokładnie w roku 2005, przez sąd w Poczdamie ${ }^{37}$. W sprawie chodziło o cierpiącą na zaburzenia pamięci kobietę, którą umieszczono w specjalnym ośrodku. Chora miała tendencje do uciekania z domu zarówno w dzień, jak i w nocy, a poza tym cierpiała na liczne schorzenia internistyczne, które wymagały systematycznego podawania jej odpowiednich lekarstw. W przeszłości zdarzało

H.-P. Mansel, w: Jauernig..., s. 60.

37 Orzeczenie Sądu Krajowego (Landgericht Potsdam) z 25.10.2005, 5T 536/05, BeckRS 2011, numer boczny 12650 . 
się, że chora przepadała na wiele godzin bez wieści, nierzadko też na skutek upadków doznawała poważnych urazów. Kilka lat wcześniej kobieta udzieliła swojemu synowi ogólnego pełnomocnictwa do sprawowania nad nią opieki, które obejmowało m.in. upoważnienie do wyrażenia w jej imieniu zgody na umieszczenie jej w ośrodku opiekuńczym, jak również do ograniczenia jej wolności w wypadkach uzasadnionych jej stanem zdrowia. Działając na podstawie udzielonego pełnomocnictwa, syn wystąpił do sądu o wyrażenie zgody na wyposażenie matki w chipa umożliwiającego personelowi ośrodka kontroli nad chorą. Sąd I instancji udzielił zgody na zainstalowanie takiego urządzenia, ograniczając jednak prawo posługiwania się nim na okres nieprzekraczający 12 miesięcy. Uznano bowiem, że posłużenie się chipem jest ostatecznością, do której odwołać można się wyłącznie wówczas, gdy nie jest możliwe zapewnienie chorej należytej opieki przy użyciu innych tradycyjnych metod. Z punktu widzenia prezentowanego opracowania interesujące są również argumenty przytoczone przez samą chorą, która zaskarżyła wspomniane orzeczenie sądu I instancji. Podniosła ona mianowicie, że urządzenia tego typu niosą ze sobą daleko idącą ingerencję w jej wolność oraz naruszają jej godność. Na skutek założenia chipa w butach chory staje się bowiem sam częścią systemu nadzorującego go, co czyni z niego techniczny obiekt nadzoru. Ten stan rzeczy nie zabezpiecza $\mathrm{w}$ istocie przed niebezpieczeństwem wyrządzenia samemu sobie szkody, jak argumentowała bowiem $\mathrm{w}$ dalszym ciągu skarżąca, tego typu urządzenia służą wyłącznie odciążeniu personelu w pracy. Sąd II instancji nie podzielił przywołanej argumentacji i ostatecznie utrzymał w mocy zaskarżone orzeczenie, choć przyznał w uzasadnieniu, że posłużenie się tego typu urządzeniami nadzorującymi narusza godność człowieka. Konstatacja ta nie oznacza jednak, że w pewnych sytuacjach wzgląd na dobro pacjenta przemawia za dopuszczeniem posługiwania się takimi zabezpieczeniami. Nie bez znaczenia w tym względzie jest nie tylko stan zaawansowania demencji oraz fakt powtarzających się ucieczek, w tym także w miesiącach zimowych, ale również dokładny sposób funkcjonowania takiego systemu. Należy uznać go za dozwolony wówczas, gdy służy on wyłącznie do ustalenia, czy chory opuścił budynek, czy też pozostaje w nim nadal, bez możliwości jednak dokładnego jego zlokalizowania.

Warte uwagi jest także rozstrzygnięcie Sądu Rejonowego $\mathrm{z}$ dnia 22.09.2008 $\mathrm{r}^{38} \mathrm{~W}$ stanie faktycznym, który legł u postaw jego wydania, chodziło o pacjenta cierpiącego na chorobę Alzheimera, umieszczonego w specjalnym

38 Wyrok Sądu Rejonowego (Landgericht) z Hildesheim z dnia 22.09.2008, 42 XVII W 1285, BeckRS, numer boczny 27411. 
centrum opieki, wyspecjalizowanym w opiece nad osobami z demencją. Pacjent ten zachował sprawność fizyczną, na skutek zmian mózgu utracił jednak całkowicie zdolność orientacji w terenie, wykazywał też typowe dla tej choroby skłonności do opuszczania bez zapowiedzi ośrodka, w którym przebywał. Aby $\mathrm{mu}$ to uniemożliwić, zgodnie z zaleceniem lekarskim, założono mu w obuwiu mały, niewidoczny chip. Nie wchodząc w szczegóły techniczne, system ten działa w sposób następujący: gdy osoba zbliżała się do drzwi wyjściowych, one zamykały się automatycznie, ich otwarcie było możliwe poprzez naciśnięcie odpowiedniego przycisku. Wykonanie tej czynności przez osobę wyposażoną w chip powodowało przesłanie niskiej frekwencji elektromagnetycznej, co powodowało zablokowanie drzwi. W konsekwencji takie osoby nie mogły samodzielnie opuścić ośrodka, było to możliwe jedynie przy pomocy osób trzecich, które rzecz jasna nie mogły być wyposażone w chipa. W ocenie sądu rozpoznającego sprawę tego typu system prowadzi do ograniczenia wolności chorego, ponieważ nie może on samodzielnie otworzyć drzwi i opuścić pomieszczenia. W ten sposób z perspektywy osoby wyposażonej w chip powstaje sytuacja tożsama z tą, w której nie może ona sama decydować o tym, czy i kiedy ewentualnie opuści ona pomieszczenie. Dlatego jej oceny nie może zmienić fakt, że jest możliwe opuszczenie pomieszczenia przy pomocy osób trzecich. W uzasadnieniu podkreślono, że $\mathrm{w}$ takich sytuacjach dla posłużenia się opisywanym urządzeniem zawsze niezbędne jest uzyskanie zgody sądu opiekuńczego. Wymóg ten nie odnosi się natomiast do systemów, których rola ogranicza się jedynie do przesłania personelowi ośrodka komunikatu o opuszczeniu budynku przez pacjenta.

Przytoczone przykłady z orzecznictwa niemieckiego dowodzą, jak wiele punktów spornych zawiera dyskusja na temat dopuszczalności wyposażania chorych w chipy umożliwiające ich lokalizację. Podsumowując, należy zauważyć, że w doktrynie niemieckiej dominuje pogląd, że wyposażenie chorego w chip prowadzi do ograniczenia wolności zawsze, gdy w konsekwencji funkcjonowania takiego systemu nie może on bez pomocy osób trzecich opuścić ośrodka, w którym przebywa. O ograniczeniu takim nie może być natomiast mowy wówczas, gdy zadaniem tego systemu jest jedynie zaalarmowanie personelu medycznego. Ostatecznie więc większość autorów uważa, że w ocenie takiej konsekwencji zastosowania tej technologii z punktu widzenia dobra pacjenta wiele zależy od okoliczności konkretnej sprawy. Z całą pewnością jednak sam fakt posłużenia się chipem nie uzasadnia jeszcze twierdzenia, że doszło do naruszenia godności pacjenta względnie innych, chronionych prawem, sfer jego osobowości. 


\section{Zakończenie}

Przedstawione podejście prawa niemieckiego wobec potrzeby ochrony osób cierpiących na demencję ujawnia zawiłość problematyki, z którą coraz częściej muszą zmierzyć się zarówno praktycy, jak i teoretycy prawa. Konsekwencje tej choroby ujawniają się na wielu płaszczyznach życia codziennego. Paląca staje się nie tylko potrzeba opracowania systemu opieki medycznej oraz socjalnej nad chorym, wsparcia organizacyjnego i finansowego zarówno jego, jak i jego rodziny, ale również rozważenia, czy tradycyjne instrumenty prawa cywilnego, takie jak np. konstrukcja faktycznej zdolności do działań, koncepcja ogólnego prawa osobowości, pełnomocnictwo, opieka czy w końcu przepisy o tzw. „testamencie pacjenta", czynią zadość aktualnym potrzebom społecznym. Na postawione pytanie nie można jeszcze udzielić jednoznacznej odpowiedzi. Nauka niemiecka znajduje się dopiero na początku drogi zmierzającej do wypracowania koncepcji ochrony takich osób. Pierwszy krok został już uczyniony, jest nim przeniesienie pojęć używanych do tej pory wyłącznie w sferze medycyny na płaszczyznę prawa cywilnego ${ }^{39}$. W konsekwencji zarówno w orzecznictwie, jak i doktrynie prawa zaobserwować można przejmowanie podstawowych zasad postępowania lekarskiego. Tak na przykład, analizując zjawisko posługiwania się nowymi technologiami w celu ochrony pacjenta, prawo to posługuje się pojęciem dobra pacjenta, formułowany jest też postulat poszanowania jego woli oraz godności.

\section{Bibliografia}

Beermann Christopher, Die Patientenverfügung, Familie Partnerschaft Recht 2010/6, Wydawnictwo C.H. Beck, s. 252-255.

Böckmann Martin, Die Demenzerkrankung als Hauptursache für Vorsorgemaßnahmen, Familie Partnerschaft Recht 2004/12, Wydawnictwo C.H. Beck, s. 648-654.

Coeppicus Rolf, Offene Fragen zum „Patientenverfügungsgesetz “, NJW 2011/29, s. 2085-2091.

Cording Clemens, Nedopil Norbert, Psychiatrische Begutachtung im Zivilrecht, Wydawnictwo Pabst Science Publishers, Lengerich 2017.

Damm Reinhard, Medizinrechtliche Grundprinzipien im Kontext von Pflege und Demenz - ,Selbstbestimmung und Fürsorge“, Medizinrecht 2010/28, Wydawnictwo Springer, s. 451-463.

Ellenberger Jürgen, w: Palandt. Bürgerliches Gesetzbuch, C.H. Beck, Monachium 2017.

Götz Isabell, w: Palandt Bürgerliches Gesetzbuch, C.H. Beck, Monachium 2017.

39 R. Damm, Medizinrechtliche Grundprinzipien ..., s. 451. 
Grunsky Wolfgang, Testierfägigkeit und Geschäftsfähigkeit, Baden-Baden 2009.

Kreicker Helmut, RFID-Technik in der Dementenversorgung - Herausforderung für das Betreuungsrecht, Neue Juristische Wochenschrift 2009/13, Wydawnictwo C.H. Beck, s. 890-894.

Lewaszkiewicz-Petrykowska Biruta, Wady oświadczenia woli w polskim prawie cywilnym, Wydawnictwo Prawnicze, Warszawa 1973.

Lichtenwimmer Andrea, Geschäfts- und Testierfähigkeit in der Praxis des Notars, w: Mathias Schmoeckel (red.), Demenz und Recht, Wydawnictwo Nomos, Baden-Baden 2010, s. 43-57.

Mansel Heinz-Peter, w: Rolf Stürner (red.), Jauernig, Bürgerliches Gesetzbuch. Kommentar, Monachium, Wydawnictwo C.H. Beck, 2015, s. 48-49.

Schäfer Mathias, Der Demenzkranke im Familienrecht, Neue Zeitschrift für Familienrecht, z. 15, Wydawnictwo C.H. Beck, s. 676-682.

Schmoeckel Mathias, Demenzerkrankungen als gesellschaftliche Herausforderung und Aufgabe für Juristen, w: Mathias Schmoeckel (red.), Demenz und Recht, Wydawnictwo Nomos, Baden-Baden 2010, s. 13-25.

Schölkopf Martin, Hoffer Heike, Das Erste Pflegestärkungsgesetz (PSG I) - Inhalte und Bedeutung für die pflegerische Versorgung, Neue Zeitschrift für Sozialrecht 2015/14, s. 521-531.

Stürner Rolf (red.), Jauernig, Bürgerliches Gesetzbuch. Kommentar, C.H. Beck, Monachium 2015, s. 2200-2202.

Thier Andreas, Entmündigung, Betreuung und Handlungsfähigkeit: Rechtshistorische Perspektiven, w: Mathias Schmoeckel (red.), Demenz und Recht, Wydawnictwo Nomos, Baden-Baden 2010, s. 75-89.

Waldhoff Christian, Die Testierfähigkeit Demenzkranker im Lichte des Verfassungsrechts, w: Mathias Schmoeckel (red.), Demenz und Recht, Wydawnictwo Nomos, Baden-Baden 2010, s. 57-75.

Weidlich Dietmar, w: Palandt. Bürgerliches Gesetzbuch, C.H. Beck, Monachium 2017.

\title{
Strony internetowe
}

http://demenz-brandenburg.de/wp-content/uploads/2017/02/Daten-Zahlen_2016-10-vonDALZG.pdf; stan na 8.10.2019 r.

https://de.wikipedia.org/wiki/Bruno_H._Schubert; stan na 8.10.2019 r.

\section{Beata GIESEN}

\section{CIVIL LAW CONCERNING THE PROTECTION OF PEOPLE WITH DEMENTIA - A STUDY FROM THE PERSPECTIVE OF GERMAN LAW}

\begin{abstract}
Background: The ageing of the population presents society with ever new challenges. Technical solutions, such as chip monitoring for dementia sufferers, are becoming increasingly important. These phenomena make it necessary for lawyers to solve a number of new, hitherto unknown problems.

Research purpose and methods: The need for comprehensive regulation of the legal situation of people suffering from dementia is becoming more and more urgent, also in Polish law. In this respect, it may be useful to draw on the experience of Western countries, in particular, German
\end{abstract}


solutions. The presentation of the experiences of our neighbours may be a good starting point for considerations under Polish law.

Conclusions: In German legal doctrine, there is a general consensus on the need to create a new philosophy that takes into account the specific situation of people suffering from chronic memory disorders and of the members of their families, who often take on the burden of care. Diseases such as Alzheimer's, for example, are accompanied by chronic dysfunctions in the process of decision-making and the expression of will. These dysfunctions often lead to questions about the actual legal capacity of people affected by such a condition, especially the issue of their representation and care. There is no total legal incapacity, but only a possibility of excluding the ability to act within the scope and appointment of a guardian appointed by the guardianship court. However, it is not possible to deprive such a person of his or her ability to make dispositions by will. Consequently, in German law, the person affected by dementia and for whom the guardianship court appoints a guardian, will have the guardian as a representative in the fields of the guardianship. However, even in these fields the guardianship, as such, does not lead to legal incapacity. The guardianship court can only impose an additional consent requirement. On the other hand, legal incapacity, as such, is irrespective of guardianship. The concept of natural legal (in-)capacity adopted in the German system seems to fully protect the person suffering from dementia from the negative consequences of measures taken by him or her in a state of exclusion or significant restrictions on the freedom to formulate his will. If memory disorders have an impact on the shaping of will, the action performed will be considered invalid. The disadvantage of this solution is undoubtedly that the evaluation of the validity of an action can only be performed ex post. The solutions adopted are an expression of the conviction that dementia patients retain the right to self-determination. Therefore, marriages and divorces are possible. Advance directives play an important role in the process of protecting patients' interests, by which a person can give prior provisions on therapy and treatment and precautional authorizations, by which a person can confer forehandedly authority to somebody else.

Keywords: Alzheimer's, guardianship, memory disorder, patients' advance directive, precautional authorization. 